Mass Medical Repatriation of Wounded Civilians in an International Terrorist Attack-Lessons Learned from the Tabba/Ras el Satan, Egypt Experience on 07 October 2004

\author{
Y. Bar-Dayan; ${ }^{1}$ A. Leiba $;{ }^{2}$ M. Peres; ${ }^{2}$ G. Weiss; ${ }^{2}$ \\ G. Horwits, ${ }^{2}$ A. Horwits; ${ }^{2}$ \\ 1. Surgeon General, Israeli Defense Force (IDF) Home Front \\ Command, Israel \\ 2. Israel
}

Introduction: Large-scale, international, terrorist attacks recently have become common-place. The need for medical repatriation of all or some of the wounded civilians could arise in such instances. On 07 October 2004, two suicide bombers crashed a car into a hotel in Taba, Egypt, and another suicide bomber in Ras el Satan in Nueba, Egypt. The Israeli Defense Force (IDF), via the Home Front Command Forces took the responsibility for the salvage, rescue, and repatriation mission. The mission requested the collaboration of the Egyptian rescue teams, the search and rescue teams of the Home Front Command, the IDF medical corps forces, the Israeli Air Force rescue teams, the Magen David Adom ambulance services, and the civilian hospitals.

Objectives: To outline the distinctive aspects of this mission, as well as to share experiences and lessons learned.

Methods: Israeli Army and Israeli National Emergency Medical Services debriefing reports were used to study the composition of the crews, distribution of injuries, mode of operation, and mission schedule.

Results: Optimal international crisis collaboration was established immediately between Israel and Egypt. Borders were opened and an efficient working collaboration began.

A total of 185 wounded Israelis were repatriated: four were severely wounded, 13 were moderately injured, and 168 were mildly injured. Thirty-two people died. A total of 168 injured people arrived at the Yoseftal hospital either by ambulances or private cars, a small hospital in the town of Eilat on the border. The hospital's emergency room was ready to receive massive numbers of-casualties (MCI) in 22 minutes. The first casualty arrived 32 minutes after the attack, and the last arrived nearly 14.5 hours after the attack. A forward team, including 23 doctors, 35 paramedics, 12 nurses, and senior IDF medical personnel with 150 units of blood were transported by the Israeli Air Force to Eilat to assist in the search and rescue operation in the field and in the local hospital. Twenty additional physicians on vacation in Eilat rapidly arrived at the hospital. Yoseftal Hospital rearranged itself as a "triage hospital" dealing with triage, life-saving treatment, life-saving surgery, and evacuation. Secondary transfer was done by ambulances and helicopters to three trauma centers in Israel, with the closest being a two-hour drive from Eilat.

Conclusions: This mode of operation provided optimal treatment to the wounded people. The principles of this operation are applicable to other cross-border, international terrorist attacks. Optimal international collaboration is critical for the success of this rescue mission. Both the attacked country and the neighboring country must con- centrate their responding forces as soon as possible. Rapid triage and evacuation, as well as the search and rescue for wounded persons in the crash area, should be done by the combined forces according to the operational advantage of each side. The small hospital near the border should receive most of the casualties and act as a "triage hospital". Medical personnel from the emergency medical services and Israel were used to reinforce the triage hospital.

Keywords: collaboration; Egypt; hospital; international; Israel; search and rescue; terrorism; treatment; triage Prebosp Disast Med 2005;20(2):s60

\section{Improving Risk Communication in Radiological Terrorism Events: Findings from a Multi-Year Research Study}

S.M. Becker

University of Alabama at Birmingham, USA

Preparing for the possibility of terrorism involving radioactive materials is now a high-priority focus for emergency response and disaster management agencies around the world. A key component of these efforts involves the development of effective risk communication strategies. This presentation reports findings from a multi-year, multi-site study of risk communication and information issues in radiological terrorism situations that is being funded by the United States (US) Centers for Disease Control and Prevention (CDC) and carried out by four major US universities. The study involved an extensive set of focus groups as well as cognitive response interviews with a range of population segments in the US. The threefold aim of the research is to: (1) better understand people's views, reactions, and concerns related to a radiological terrorism event; (2) identify people's specific information needs and preferred information sources; (3) pretest draft television, radio and printed informational materials; and (4) gain specific insights into ways of improving emergency messages for radiological terrorism situations. In this presentation, major findings from the first two years of the project are reviewed, and the implications of the research for developing messages in radiological/nuclear terrorism situations are explored.

Keywords: assessment; communication; radiological/nuclear; risk; terrorism

Prehosp Disast Med 2005;20(2):s60

Demystifying Bioterrorism: Misinformation and Misperceptions

M. Hopmeier; ${ }^{1}$ E. Noji; ${ }^{2}$ T. Goodwin, ${ }^{3}$ S. Lillibridge ${ }^{4}$

1. Unconventional Concepts, Inc., USA

2. CDC, Bioterrorism Preparedness Program, USA

3. Unconventional Concepts, Inc, USA

4. University of Texas, School of Public Health,USA

The true threat of bioterrorism remains mysterious and elusive to the common citizen. It principally has become the dominion of a few "experts", many of whom apparently have limited expertise, have failed to communicate to society the risks and realities effectively, and instead have created an air of uncertainty surrounding the topic. 